\title{
Choosing floating macrophytes for ecological intensification of small-scale fish farming in tropical areas: a methodological approach
}

\author{
Jacques Slembrouck ${ }^{1,3}$, Reza Samsudin ${ }^{2}$, Brata Pantjara ${ }^{2}$, Ahmad Sihabuddin $^{3}$, Marc Legendre ${ }^{1}$ and \\ Domenico Caruso ${ }^{1, *}$ \\ ${ }^{1}$ ISEM, Université de Montpellier, CNRS, IRD, EPHE, Montpellier, France \\ 2 RIFAFE, Bogor, Indonesia \\ ${ }^{3}$ IRD, Jakarta, Indonesia
}

Received 4 March 2018 / Accepted 1 August 2018

Handling Editor: Nicole Richoux

\begin{abstract}
Several ecological services and functions are attributed to macrophytes, which may represent valuable resource for the ecological intensification of tropical fish farming. However, considering the multiple potential eco-services provided by macrophytes, the choice of the most appropriate species requires multiple criteria to assess these eco-services. Five floating macrophytes (Eichhornia crassipes, Lemna minor, Azolla filiculoides, Salvinia molesta and Salvinia spp.) were selected for this study. The six ecoservices parameters compared among these macrophytes were: productivity (in \% of seeded macrophytes), risk of non-productive cycles, nutritional value, impact on water quality, palatability (expressed as the percentage of plant ingested in $4 \mathrm{~h}$ ) and ease of use. Experiments to determine these indicators were carried out in simple devices (net cages and plastic tanks) partially immerged in earthen ponds. The palatability of fresh macrophytes (whole or chopped) was studied in ponds using Osphronemus goramy juveniles. All indicators were scored from 1 to 5 , and the highest score was assigned to the highest performer. These scores corresponded either to the evaluation of a single parameter (e.g. productivity) or to the average from scores of several parameters (e.g. nutritional score). Multiplier coefficients were applied for nutritional value and palatability. Azolla filiculoides showed the best scores for productivity; L. minor for nutritional value and palatability, and E. crassipes for the lowest risk of non-productive cycles and a positive impact on water quality. After integrating the scores in a multi-parameter matrix, A. filiculoides had the best overall score. The results of this approach to select macrophytes are discussed in light of the eco-services provided by macrophytes which may, in turn, promote the ecological intensification of tropical small-scale aquaculture.
\end{abstract}

Keywords: Ecological intensification / tropical aquaculture / macrophytes / small-scale / alternative feed / eco-services

\section{Introduction}

The aquaculture production, amounting about 110 million tons and worth 243 billion USD, has surpassed fishery production and contributes now to more than half of the total human consumption of fishery products. Almost $90 \%$ of this production occurs in Asian countries (FAO, 2018). In future, the world demand in aquatic products for human consumption is expected to increase significantly. Considering the stagnation of global wild-caught fish resources, this demand is

\footnotetext{
${ }^{*}$ Corresponding author: domenico.caruso@ird.fr
}

expected to be satisfied through aquaculture production. This global rise in the worldwide demand for fish intended for human nutrition poses a double challenge for aquaculture: higher production to meet the growing demand for aquatic products and environmental preservation. On a broader level, aquaculture needs to develop in a sustainable way. It is forecast that aquaculture production will adapt to the fast growing demand of aquatic products by increasing its current production level. Because the expansion of productive areas and the availability of water are limited, this increase will probably occur through an intensification of current traditional production systems (Bosma and Verdegem, 2011). As for other agro-ecosystems, intensification of conventional 
aquaculture goes hand in hand with a simplification of the productive system replacing biological functions with massive use of feed, fertilizer and other industrial inputs (Aubin et al., 2017). According Tacon and Metian (2015), more than $70 \%$ of global aquaculture depends on external feed inputs. Therefore, small-scale fish farming, which represents a large part of the worldwide aquaculture production, must cope with increasing production costs, commercial competition and limited technical resources, all of which may reduce its sustainability. In Indonesia, small scale fish farming is prominent and represents more than $80 \%$ of aquaculture farms (Phillips et al., 2015). Nevertheless it is considered as vulnerable and small scale fish farming faces several challenges in terms of sustainability, particularly regarding quality and availability of fish feeds (Elfitasari and Albert, 2017). Despite a relatively low level of individual production (1.4 tons per year per fish farmer in Indonesia), small-scale farming is, in Indonesia such elsewhere, considered as a "cash-crop" production (Kawarazuka and Béné, 2010) and fish and shellfish generally represent a significant part of consumer expenditures in lowincome countries (Tacon and Metian, 2018). Furthermore, considering the positive impact of rural aquaculture on social structure, development and sustainability, enhancing smallscale fish farming is a major issue for these countries (Bosma and Verdegem, 2011). For small-scale fish pond producers, a possible alternative to conventional intensification may be "ecological intensification". Derived directly from the principles of agroecology, ecological intensification involves either the limitation of anthropogenic inputs without impairing crop productivity or increased productivity without using supplementary exogenous inputs, through a better use of endogenous resources or functions of the ecosystem (Soto et al., 2008; Bommarco et al., 2013; Aubin et al., 2014, 2017). Ideally, an innovative productive system, well adapted to small-scale fish farming, is little dependent on external inputs and favours the utilization of renewable resources to ensure their regeneration. Such systems, defined by Griffon (2010) as "ecologically intensive", are common in tropical aquaculture. In this human-made agro-(aqua-) ecosystem, generally highly productive, macrophytes can benefit from very favourable conditions for their growth. Macrophytes are a very interesting source of feed for omnivorous/herbivorous fish (Hasan and Rina, 2009) and they can contribute to the diet of many farmed fish species in tropical areas (Y1lmaz et al., 2004; Fiogbé et al., 2004; Velásquez, 2016). Furthermore, floating macrophytes may have positive effects for improvement of water quality and remediation of aquaculture effluents (Sipaúba-Tavares et al., 2002; Henry-Silva and Camargo, 2006; Carlozzi and Padovani, 2016). These eco-services may be beneficial for increasing the sustainability of fish farming, especially for small-scale fish farming in tropical countries. In Indonesia, the giant gourami (Osphronemus goramy) is one of the main freshwater commodities and it has been reared for decades in West Java in traditional small-scale aquaculture ponds. Although, this fish species has an omnivorous diet with a strong vegetarian component, our observations (Caruso, unpublished data) indicated that floating macrophytes are only sporadically used by fish farmers to feed fish and this practice is largely empirical. Fish farmers do not perceive the ecosystem services offered by macrophytes as an opportunity, and generally have low consideration for this natural resource that may increase the efficacy and reduce inputs (fish feed) of their own production system. This disregard may explain, at least in part, the low integration of macrophytes in farm. Additionally, the use of macrophytes by fish farmers may depend on several factors such as their consistent availability, nutritional value and acceptance by fish. These factors may greatly vary according to production systems, ecological conditions, and also to the specific priorities of each fish farmer. Therefore, the choice of macrophyte depends on multiple factors that need to be objectively evaluated and scored. In this study, we developed a multi-factor screening method to help choose the most appropriate species amongst a panel of floating macrophytes and promote their rational use for ecological intensification in tropical small-scale fish farming.

\section{Materials and methods}

Five floating macrophytes species were considered in this study. Although some are not native species, all are well established in most aquatic ecosystems of West Java. Macrophytes studied were the water hyacinth (Eichhornia crassipes), duckweed (Lemna minor), azolla (Azolla filiculoides) and two types of salvinia (Salvinia molesta; Sm1, Sm2) differing in size; the smallest was called Sm2. Species identification was confirmed by botanists from the Department of Fisheries Resources Utilization, Bogor Agricultural University in Indonesia.

Experiments on macrophyte productivity and their impact on water quality were carried out in an earthen pond, without fish, located in a fish farm of the village of Babakan $\left(6^{\circ} 28^{\prime} \mathrm{S}\right.$; $106^{\circ} 42^{\prime} \mathrm{E}$; altitude $\left.125 \mathrm{~m}\right)$, West Java, Indonesia. The pond $\left(200 \mathrm{~m}^{2}\right.$, depth $\left.0.33 \mathrm{~m}\right)$ was emptied, cleaned of its mud, limed $(25 \mathrm{~kg})$, then fertilized with chicken manure mixed with rice bran $(125 \mathrm{~kg})$ and urea $(5 \mathrm{~kg})$. One week later, the pond was filled with water from the Setu Cilala Reservoir, and then macrophytes were seeded in two types of experimental receptacles as detailed below.

The first receptacle consisted of nylon net cages reinforced by a PVC frame (inner dimensions $0.8 \times 0.8 \times 0.5 \mathrm{~m}$ ). The mesh size used was small $(1 \mathrm{~mm})$, to avoid the loss of small macrophytes, particularly L. minor. Fifteen similar net cages ( 3 replications for each macrophyte tested) were set in the pond using bamboo poles. Each cage was seeded with one the five tested macrophyte taxa, then harvested every three days. This time period corresponds to the duration of one cycle of production. Two seeding quantities were tested (200 and $400 \mathrm{~g} \mathrm{~m}^{-2}$ respectively) for all macrophytes except the water hyacinth. For this macrophyte, four seeding quantities were tested $\left(200,400,500\right.$ and $\left.1000 \mathrm{~g} \mathrm{~m}^{-2}\right)$.

In this device, the following indicators were assessed:

- Productivity, defined as the weight gain of macrophytes in $\mathrm{g} \mathrm{m}^{-2}$ day $^{-1}$ expressed in percent of seeded macrophyte biomass

- Risk of non-productive cycles, defined as the probability of risk of a productivity of $\leq 0 \%$ of seeded macrophyte biomass. It was calculated by dividing the occurrence of this event by the total number of production cycles. Its value varies between 0 and 1 .

- Nutritional value, determined from three proximate analyses of macrophytes. Analyses were performed 
following AOAC methods (1999). Moisture was determined by weight loss upon drying at $105^{\circ} \mathrm{C}$ for $3 \mathrm{~h}$. Crude protein was determined using the standard Kjeldahl procedure (Foss Tecator Kjeltec 8400 and Kjeltec Bucchi); lipid content after acid hydrolysis was determined using the Weibull-Stoldt method; crude ash by determining residue after heating at $550{ }^{\circ} \mathrm{C}$ for $4-5 \mathrm{~h}$ in a muffle furnace and crude fibre was determined as follows: macrophytes were extracted with $1.25 \% \mathrm{H}_{2} \mathrm{SO}_{4}$ and $1.25 \% \mathrm{NaOH}$, then dried and samples were weighed, incinerated and reweighed. Gross energy content was calculated using energy value coefficients of $9 \mathrm{kcal}$ for crude fat and $4 \mathrm{kcal}$ for crude protein and carbohydrates.

The second type of experimental receptacle was set up using a half plastic drum (cut along its length; $50 \mathrm{~L}, 0.43 \mathrm{~m}^{2}$ ) partially immerged in the pond and maintained by bamboo poles. Eighteen of these receptacles (3 repetitions for each macrophyte and for control without macrophytes) filled with water from the pond were used to determine the effects of macrophytes on the physico-chemical parameters of water (water remediation indicator). Water samples $(500 \mathrm{~mL})$ from each plastic drum were collected every 3 days (between 08:00 and 09:00 a.m.) for 15 consecutive days. The water parameters listed below were considered as indicators of water remediation:

- Water remediation. Dissolved oxygen (DO), temperature, $\mathrm{pH}$, total dissolved solids (TDS) and turbidity were measured in situ using a multi-parameter probe (HI 9829 Hanna). Water samples were collected and stored in a cooler at $4-5^{\circ} \mathrm{C}$, then analysed at the laboratory less than $6 \mathrm{~h}$ after sampling. Ammonium nitrogen $\left(\mathrm{NH}_{4}{ }^{+}-\mathrm{N}\right)$, ammonia nitrogen $\left(\mathrm{NH}_{3}-\mathrm{N}\right)$, nitrite $\left(\mathrm{NO}_{2}{ }^{-}-\mathrm{N}\right)$, nitrate $\left(\mathrm{NO}_{3}{ }^{-}-\mathrm{N}\right)$, orthophosphate $\left(\mathrm{PO}_{4}^{3-}\right)$ were determined using a spectrophotometer (Hach DR/2010). Results observed in the drums with macrophytes were compared with those obtained in the control without macrophytes.

A specific experiment, repeated 10 times, was designed to determine the relative acceptance of macrophytes by giant gourami juveniles. To do so, 216 fish (body mass $56.5 \pm 1.3 \mathrm{~g}$; total length $14.9 \pm 0.12 \mathrm{~cm}$ ) were placed in a concrete pond $(7.5 \times 5.5 \times 0.65 \mathrm{~m})$. In the same pond, $200 \mathrm{~g}$ of each macrophyte were placed in five different floating frames $(0.8 \times 0.8 \mathrm{~m})$, to make all macrophytes equally accessible to the fish. To avoid habituation related to the (relative) position of macrophytes, their distribution was randomly changed for each frame every day. The two following indicators were considered:

- Palatability, defined as the quantity of macrophyte ingested by fish during a given period of time (expressed in $\%$ of quantity given). Here, this period lasted $4 \mathrm{~h}$, because giant gourami do not have gluttonous behaviour.

- "Ease of use", evaluated both from the structure and size of the macrophytes and the work needed by farmer to provide appropriate macrophyte size to fish, i.e. involving cutting, crushing and/or grinding leaves or raw plants. Since these processes are tedious and require manpower, this additional work may deter fish farmers. The indicator "ease of use" was evaluated qualitatively for the relative ranking of macrophytes.

\subsection{Statistics and scoring evaluation}

Normality and equal variance conditions were tested respectively using the Shapiro-Wilks test and Brown-Forsythe test. Correlation between initial amount of seeded macrophytes and productivity expressed as $\mathrm{g} \mathrm{m}^{-2}$ day $^{-1}$ in percentage of seeded macrophyte biomass was tested using Spearman correlations. For parameters of proximate analysis of macrophytes, differences between macrophytes were tested using a one-way ANOVA followed by Tukey's post hoc test. When the conditions of normality and equal variance were not met, the Kruskal-Wallis one-way ANOVA on ranks and Dunn's post-hoc test were used for productivity, palatability water parameters and the different levels of initial seeding in E. crassipes. The MannWhitney rank sum test was applied to test the two seeding levels ( 200 and $400 \mathrm{~g} \mathrm{~m}^{-2}$ ) of all the other macrophytes. For all tests, $\alpha$ was 0.05 . To provide a synthetic indication of the best aquatic macrophytes, a matrix of the scores obtained by the six indicators was constructed. For each quantitative indicator, the score of each plant was directly attributed according to its median or mean value, instead of considering statistical result comparisons, in order to maximize the discriminant power of the indicators. The different macrophyte species were then ranked from 1 to 5 giving the highest score for the best condition. The indicators were represented either by a single parameter (productivity, risk of non-production, palatability and ease of use scores) or by the average of the respective scores of several parameters (nutritional value and water remediation). Because feeding characteristics are considered as the main constraints for fish culture, the two indicators related to the feeding value (nutritional score and palatability) were weighted by a coefficient of 1.5 .

\section{Results}

\subsection{Nutritional value}

The average results of proximate analyses on macrophytes are presented in Table 1. Significant differences between macrophytes were found for mean energy content (ranging from 12.3 to $15.4 \mathrm{MJ} \mathrm{kg}^{-1} ; P=0.021$ ), protein content (ranging from 14.6 to $34.8 \% \mathrm{DM} ; P=0.019$ ) and ash (ranging from 16.7 to $29.1 \% \mathrm{DM} ; P=0.033$ ). To score the macrophytes for their nutritional values, four parameters were selected: energy in $\mathrm{MJ} \mathrm{kg}^{-1}$ (Dry Matter; DM), protein content, crude fat (ether extract) and crude fibre in \% DM. The content of plants in carbohydrates was not considered for ranking macrophytes since they may correspond either to useful nutrients or to indigestible materials such as cellulose. Fibres are considered as an anti-nutritional factor; therefore, the fibre content was ranked as a negative characteristic, giving the highest score to the lowest level of crude fibre. The corresponding scores attributed to the macrophytes for their nutritional value are summarized in Table 1.

\subsection{Productivity}

A total of 403 production cycles were harvested during the study. Among them, 330 cycles led to a positive production and the productivity of macrophytes was calculated on all production cycles except those having negative production 
Table 1. Proximate analysis of five floating aquatic macrophytes and relative scores related to nutritional value. Except for crude fibre $(*)$, all data are expressed as the mean \pm SEM (standard error of the mean; $n=3$ ) and are expressed in percentage of dry matter $(\%$ DM). Values in the same column with the same letter are not significantly different at $P>0.05$. (*) Only one analysis.

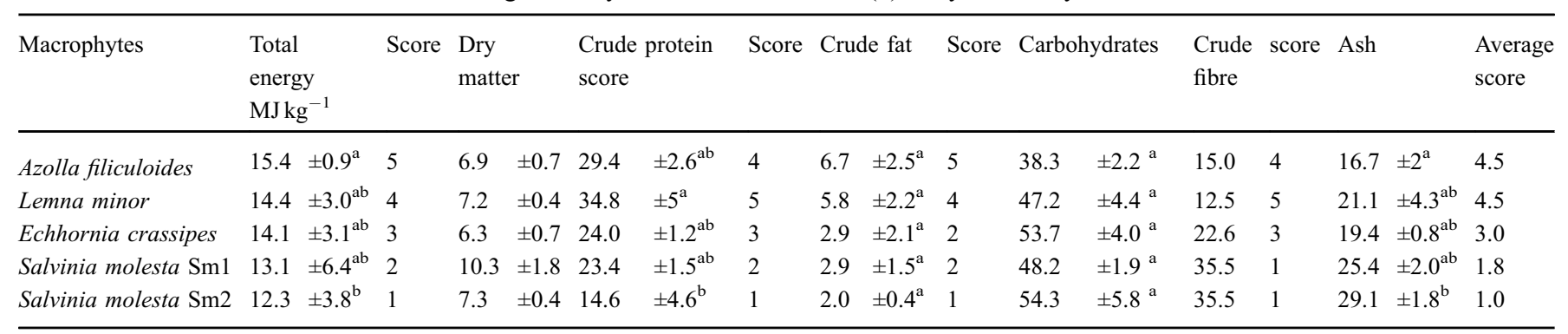

Table 2. Characteristics of productivity observed during the production cycles of aquatic macrophytes in tropical aquaculture ponds. Values in the same column with the same letter are not significantly different at $P>0.05$ (Kruskal-Wallis ANOVA). ${ }^{*}$ For E. crassipes, leaf biomass is given in parentheses.

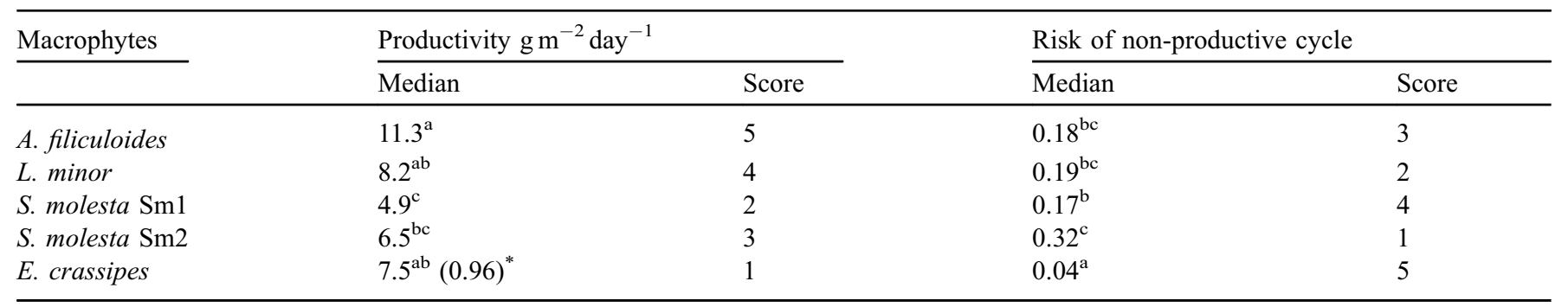

levels $(n=73)$. Productivity of macrophytes varied between 4.9 and $11.3 \mathrm{~g} \mathrm{~m}^{2} \mathrm{~d}^{-1}$ and showed significant differences (median, ANOVA on ranks, $P<0.001$; Table 2). The highest score was attributed to $A$. filiculoides, and the ranks attributed to other macrophytes decreased with decreasing productivity. However, in the case of E. crassipes, only leaves could be used to feed fish and they represented only $12.8 \pm 0.42 \%$ of the biomass produced by the plant. Given this low amount of edible parts, E. crassipes was given the lowest score (1). However, overall, the initial amount of seeded material was not correlated with daily production $(0.066 / 0.235$ Spearman correlation). Individually, duckweed and water hyacinth showed significantly different daily production between initial seeding amounts, but differences were not significant for the three other macrophytes (Fig. 1).

\subsection{Risk of non-productive cycles}

There was high variability in the risk of non-productive cycles and, overall, macrophyte production collapsed in $18 \%$ of production cycles. The risk of no production varied between 0.04 and 0.32 (median values) and differed significantly between macrophytes (ANOVA on ranks, $P<0.05$; Table 2). For this indicator, the score attributed to every macrophyte decreased with the increased risk of non-production.

\subsection{Palatability}

The percentages of macrophyte ingested by gourami fingerlings in $4 \mathrm{~h}$ as a function of the plant distributed are presented in Figure 2. Lemna minor was highly appreciated by gourami and was always completely eaten by fish. The palatability of $L$. minor was clearly greater than that of all other macrophytes (ANOVA on ranks; $P<0.001$ ) except $A$. filiculoides $(P=0.090$; Fig. 2). There was no effect related to the position of the distribution of macrophytes in the pond (ANOVA on ranks; $P=0.750$ ). The macrophytes were scored as a function of their respective rank of palatability.

\subsection{Water remediation}

The results of the water parameters $\mathrm{NH}_{4}^{+}-\mathrm{N}, \mathrm{NO}_{3}{ }^{-}-\mathrm{N}$, $\mathrm{DO}, \mathrm{pH}$, and TDS, for which a significant difference was found relative to the control, are shown in Table 3. Since a decrease in DO relative to the saturation value $\left(7.3-7.9 \mathrm{mg} \mathrm{L}^{-1}\right)$ may have a negative impact on fish well-being and health, the score was ranked from high to low DO values. Conversely, the increase in $\mathrm{NH}_{4}^{+}-\mathrm{N}, \mathrm{NO}_{3}{ }^{-}-\mathrm{N}$ or TDS levels was scored negatively, the lowest score being given to the highest value. Due to large variations in $\mathrm{pH}$ observed in the control, this parameter was excluded from the scoring matrix.

\subsection{Ease of use}

Only L. minor and A. filiculoides were used whole owing to their small size; the roots of E. crassipes and S. molesta ( $\mathrm{Sm} 1$, $\mathrm{Sm} 2$ ) were removed and the leaves of E. crassipes were cut into pieces. Consequently, the score attributed to the latter macrophyte was the lowest (1). A score of 2 was given to 


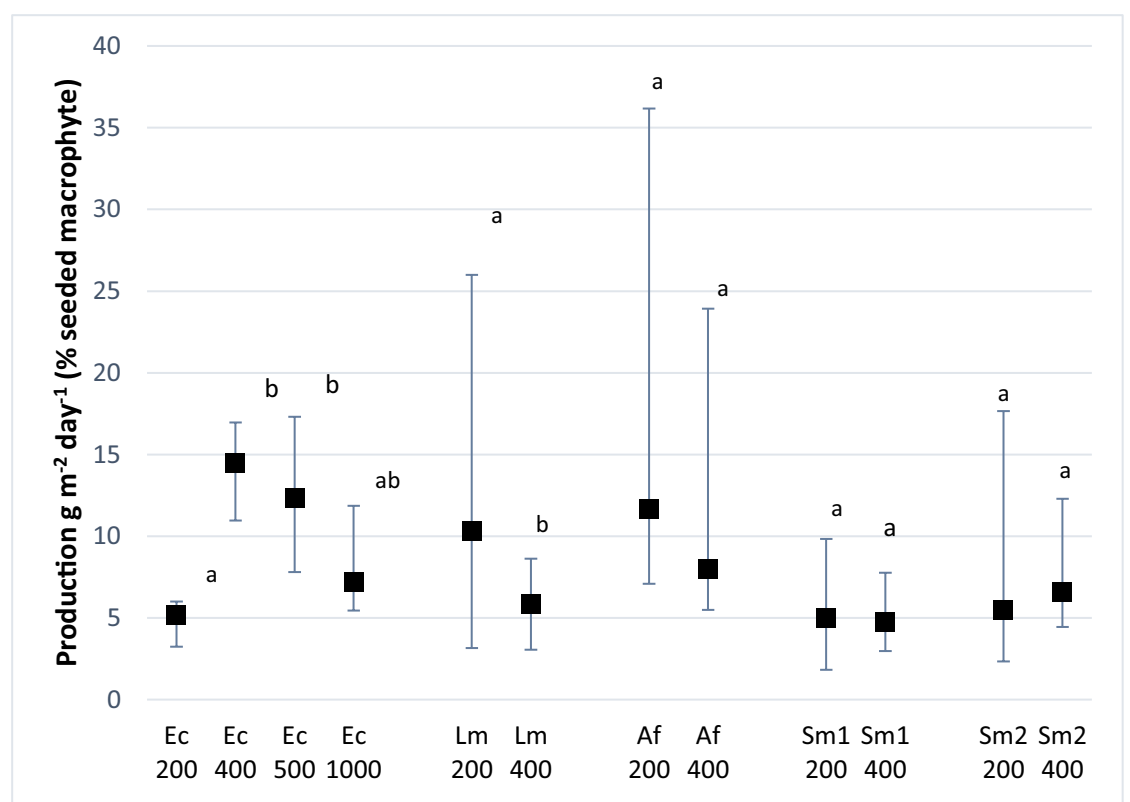

Fig. 1. Production $\left(\mathrm{g} \mathrm{m}^{-2} \mathrm{day}^{-1}\right)$ in \% seeded macrophytes according to level of seeding. Lm: Lemna minor; Af: Azolla filiculoides; Sm1: Salvinia molesta type1; Sm2: Salvinia molesta type 2; Ec: Echhornia crassipes. Data are expressed as the median and 25\% and $75 \%$ quartiles. Treatments with the same letter indicate no difference between seeding levels for a given taxon $(P=$ Kruskal-Wallis ANOVA on ranks for Ec; Mann-Whitney rank sum test for all other macrophytes).

S. molesta $\mathrm{Sm} 1$, a score of 3 was attributed to $S$. molesta $\mathrm{Sm} 2$ with smaller leaves than Sm1. A score of 4 was given to $A$. filiculoides and the best score (5) was given to L. minor, which was the smallest macrophyte tested and the easiest for fish to consume.

\subsection{Cumulative scoring}

The results of the multi-parameter evaluation of ecoservices for the tested floating macrophytes are presented in Figure 3. Azolla filiculoides appears as the macrophyte with the highest potential for ecological intensification of gourami grow-out ponds with a total score of 28 , followed very closely by L. minor (27). Eichhornia crassipes presented an intermediate ranking with a score of 20 . The two $S$. molesta, Sm1 and Sm2, ranked far behind with global scores of 16 and 13 , respectively.

\section{Discussion}

With the rising cost of feed and concerns about the sustainability of aquaculture, the use of macrophytes has gained attention and may be a very interesting option for feeding omnivorous/herbivorous fish (Mandal et al., 2010; Akmal et al., 2014). Floating macrophytes can be a valuable way to increase or enhance the use of the ecological processes and natural resources. In aquaculture systems, macrophytes can be considered either for fish feeding or for water remediation, both may help to improve the ecosystem integration of aquaculture production. For example, Azolla sp. are recognized as important biological sources of nitrogen for agriculture and the animal industry. They have

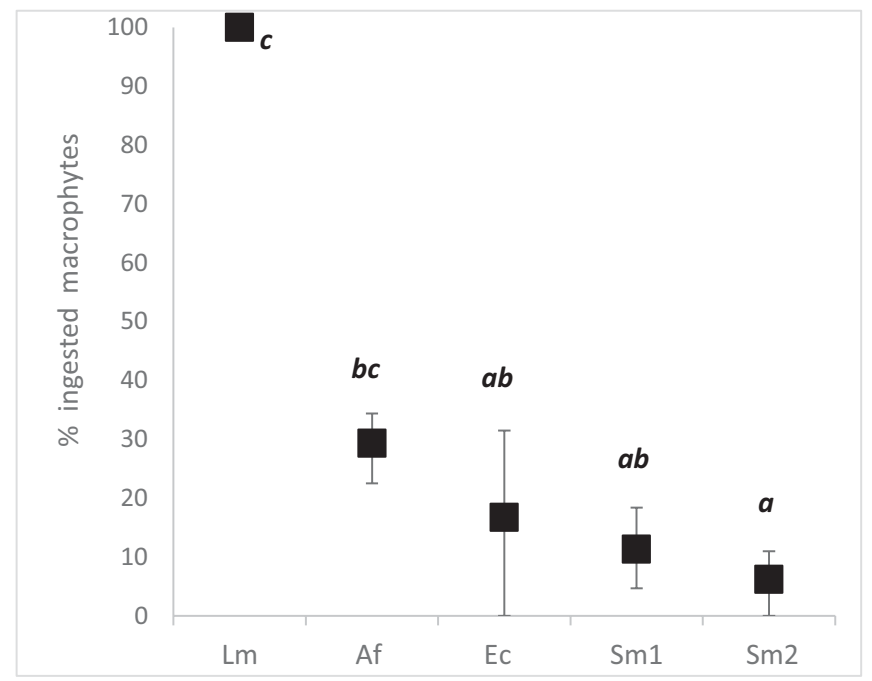

Fig. 2. Palatability of five floating macrophytes for the giant gourami (Osphronemus goramy) in \% ingested macrophytes over a period of $4 \mathrm{~h}$. Data are shown as the median and $25 \%$ and $75 \%$ quartiles. Lm: Lemna minor; Af: Azolla filiculoides; Sm1: Salvinia molesta type1; Sm2: Salvinia molesta type 2; Ec: Echhornia crassipes. Treatments with the same letter are not significantly different (Kruskal-Wallis ANOVA).

a good potential for water bioremediation and can greatly mitigate agricultural greenhouse gas emissions, particularly in flooded rice ecosystems (Kollah et al., 2016). In our multiparameter evaluation, A. filiculoides attained the best overall value, although it did not have the best score for all the parameters studied here. There are reports that its 
Table 3. Median values of water quality parameters differing significantly between floating macrophyte treatments $(n=15$; Kruskal-Wallis ANOVA). Asterisks indicate significant differences compared with the control (without macrophytes): Dunn's methods. $\mathrm{pH}$ was not scored due to its high variability in the control (see text).

\begin{tabular}{|c|c|c|c|c|c|c|c|c|c|c|}
\hline Macrophytes & $\begin{array}{l}\mathrm{NH}_{4}^{+}-\mathrm{N} \\
\left(\mathrm{mg} \mathrm{L}^{-1}\right) \\
P=0.013\end{array}$ & Score & $\begin{array}{l}\mathrm{NO}_{3}{ }^{-}-\mathrm{N} \\
\left(\mathrm{mg} \mathrm{L}^{-1}\right) \\
P=0.005\end{array}$ & Score & $\begin{array}{l}\text { Dissolved } \\
\text { oxygen (DO) } \\
\left(\mathrm{mg} \mathrm{L}^{-1}\right) \\
P<0.001\end{array}$ & Score & $\begin{array}{l}\mathrm{pH} \\
P<0.001\end{array}$ & $\begin{array}{l}\text { Total dissolved } \\
\text { solids (TDS) } \\
\left(\mathrm{mg} \mathrm{L}^{-1}\right)\end{array}$ & $\begin{array}{l}\text { Score } \\
P<0.001\end{array}$ & $\begin{array}{l}\text { Average } \\
\text { score }\end{array}$ \\
\hline Lemna minor & 0.09 & 4 & $0.30^{* *}$ & 1 & $5.78^{* * *}$ & 2 & $7.16^{* *}$ & 40 & 1 & 2.0 \\
\hline Azolla filiculoides & $0.17^{*}$ & 1 & 0.10 & 5 & $5.57^{* * *}$ & 1 & $6.59^{* * *}$ & $19^{* * *}$ & 5 & 3.0 \\
\hline Salvinia molesta $\mathrm{Sm} 2$ & 0.16 & 2 & $0.20^{*}$ & 3 & $5.87^{* * *}$ & 3 & $6.77^{* * *}$ & $33^{* *}$ & 1 & 2.3 \\
\hline Echhornia crassipes & 0.04 & 5 & 0.20 & 2 & 7.27 & 5 & $7.06^{* * *}$ & $26^{* * *}$ & 4 & 4.0 \\
\hline Control & 0.05 & - & 0.10 & - & 8.82 & - & 8.87 & 46 & - & - \\
\hline
\end{tabular}

${ }^{* * *} P<0.001 ;{ }^{* *} P<0.01 ;{ }^{*} P<0.05$

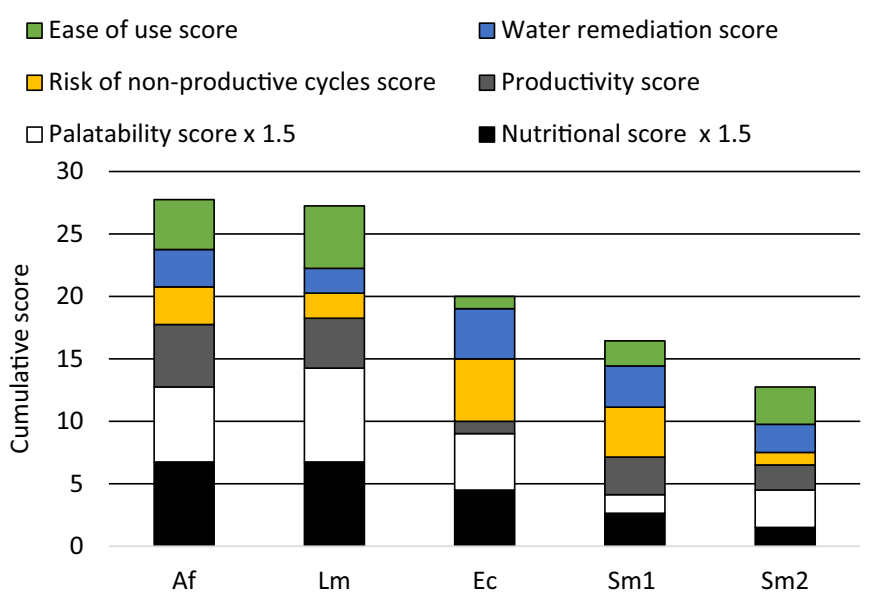

Fig. 3. Multi-parameter evaluation of eco-services and quality of floating macrophytes tested. Palatability determined for giant gourami (Osphronemus goramy). Af: Azolla filiculoides; Lm: Lemna minor; Ec: Echhornia crassipes; Sm1: Salvinia molesta type1; Sm2: Salvinia molesta type 2.

productivity may exceed $20 \mathrm{t}$ (DM) per hectare per year (Muradov et al., 2014). However, this very high level of biomass production is observed in water sewage systems, where water quality is not compatible with aquaculture. In comparison, plant productivity would probably be much lower if floating macrophytes are co-cultured in an aquaculture pond ecosystem. According to our observations, production can exceed $6 \mathrm{t}$ (DM) dry matter of $A$. filiculoides per ha year ${ }^{-1}$. This value is similar to that reported by Redding et al. (1997) but slightly less than that reported by Reddy and De Busk (1985) for A. caroliniana. In rearing conditions with regular inputs of nutrients from fish feeding and their metabolic wastes, higher levels of production can be realistically obtained. All macrophytes showed production collapses in at least one trial. For A. filiculoides, Shiomi and Kitoh (2001) suggested that a decrease in biomass production in pond water may arise from a deficiency in phosphorus and magnesium. These elements may be involved in our study in light of the non-renewal of water and the lack of new nutrient inputs. Other factors such as macrophyte density, light, wind and water flow are also involved in the regulation of macrophyte growth (Barko et al., 1982; Carr et al., 1997; Iqbal, 1999). High variability in production level will probably be the rule when co-culturing floating macrophytes in an aquaculture ecosystem, because many environmental factors regulate their growth (Hasan and Rina, 2009).

In terms of nutritional value, gross energy content is an important requirement for fish feed and here the level of crude fat in macrophytes was considered positively because it increases the energy content, which is generally low for macrophytes in comparison with other sources of feed used in tropical aquaculture. Carbohydrates in green macrophytes are mainly composed of cellulose, hemicellulose and other complex carbohydrates that can negatively affect the digestibly of plants by fish. However, simple sugars are also present and can be a good source of energy even if their digestibility may vary. Dry matter depends on water content, and low levels may indicate lower nutritional value of macrophytes; however, in the case of plants, high levels may also correspond to high content of indigestible fibre. Thus, we excluded carbohydrate content from scoring evaluations. By contrast, crude fibre content was considered as a negative component because it corresponds mainly to true cellulose and lignin, both indigestible for fish. Although more accurate analyses would be useful (Neutral Detergent Fiber NDF, Acid Detergent Fiber ADF, lignin), crude fibre provides a global view and is more easily determined by non-specialized laboratories. Despite data on the chemical composition of the main aquatic macrophytes available in literature, analyses must be carried out because the composition of floating macrophytes undergo significant variability according to the areas and conditions of production (Goopy and Murray, 2003). It is well known that plant-derived feed may contain several anti-nutritional factors (ANF), such as trypsin, protease inhibitors, lectins, tannin, oligosaccharides, soy antigens, phytoestrogens, phytic acid, antivitamins and saponins (Dersjant-Li, 2002; Drew et al., 2007), all and any of which may impair the nutritional value of plant-based feed. The presence of similar compounds in macrophytes is not well known, and specific investigations may be required to better 
characterize the presence and effects of ANF for macrophytes used as fish feed. Digestibility and absorption of nutriments of macrophyte origin clearly require more in-depth studies, particularly to elucidate interactions between digestibility, enzymatic processes and microbiome activity involved in the degradation and absorption of macrophytes (Gaitlin et al., 2007).

Information on palatability of macrophytes or raw plants remain scarce fish. Fish taste preferences are related to a complex mechanism involving mainly genetic profiling, environmental conditions and dietary characteristics of feed composition (for review, see Kasumyan and Döving, 2003; Gaitlin et al., 2007). Our study has shown that when the giant gourami has a choice of macrophytes, L. minor has the highest palatability. Nevertheless, when no choice was given, $A$. filiculoides and L. minor had similar palatability (data not show). Complementary observations indicated that chopping the leaves improved the palatability of the plants, and this processing was very efficient especially for E. crassipes and Salvinia spp. Other processing methods, particularly the fermentation of fresh floating macrophytes, may improve digestibility and intake by fish (Bairagi et al., 2002). Fermentation is required to increase the level of macrophyte incorporation in tilapia diets (El-Sayed, 2003; Velásquez, 2016). Clearly, the palatability of macrophytes depends on the fish species and can be enhanced through different types of processing. Small size macrophytes, such as Azolla and Lemna, which can be ingested whole even by small fishes, have an obvious advantage over larger macrophytes that need to be processed. Generally, small size macrophytes can be used to feed a broader range of fish of different sizes than bigger plants. Due to their large immerged root structures making access to their edible aerial leaves difficult, E. crassipes was not ingested at all by gourami juveniles. Thus, their roots and stems had to be discarded and their leaves cut before being distributed to and ingested by the fish. The reduced edible portion and the need to cut leaves before distribution compromised the "productivity" and "ease of use" scores assigned to this macrophyte. Ultimately, the "ease of use" indicator may comprise a high practical value and represent a major criterion for the final choice of macrophyte by fish farmers.

Eichhornia crassipes had the highest positive effects on water quality. This result is consistent with the review of Dhote and Dixit (2009) and with observations of Henry-Silva and Camargo (2006) who reported that this macrophyte has higher potential than $S$. molesta to reduce nutrients from tilapia pond effluents. Several other studies have demonstrated that smaller macrophytes, such as Azolla and Lemna, also have high bioremediation potential, particularly with regard to dissolved nitrogen and phosphorus (Madsen and Cedergreen, 2002; Ferdoushi et al., 2008). Absorption of nutrients by aquatic macrophytes is influenced both by the increase in biomass and by the concentration of nutrients in plant tissues. However, nitrogen absorption from water by $A$. filiculoides was the worst among the plants tested here. This result is probably strongly related to the symbiotic association of Azolla with Anabaena sp., a cyanobacterium which can fix atmospheric nitrogen (Newton and Herman, 1979). Interestingly, in control tanks, the water quality parameters were often better than in macrophyte tanks. This may be related to a higher phytoplankton activity due to a higher light penetration in the water column. Phytoplankton and periphyton activity can be very efficient to reduce nitrogen and phosphorus levels in water, often more efficient than that of E. crassipes or other macrophytes (Crispim et al., 2009). Special attention should be paid to prevent the complete covering of the water surface by plants because this can reduce phytoplankton growth. It is also important to regularly harvest aquatic plants (Azolla or other macrophytes) to reduce their decomposition in the pond. Their decay may release nutrients $(\mathrm{N}$ and $\mathrm{P})$, thereby significantly and paradoxically contributing to pond water pollution. Equilibrium between harvest and the maintenance of sufficient coverage ensuring production compatible with the expected eco-services is required for good macrophyte management.

Despite the interesting perspectives and potential of integrating floating macrophytes in small-scale fish farming, their use in aquaculture remains limited. Floating macrophytes are often perceived as a nuisance, particularly if their dispersion in the environment is not controlled. Although sometimes used by fish farmers, three of the macrophytes species studied here (E. crassipes, S. molesta $\mathrm{Sm} 1$ and $\mathrm{Sm} 2$ ) are listed in the top 100 of worst invasive species (ISSG, 2015). Beyond the ecological impacts that macrophytes can have in these conditions, their rapid growth may induce competition for water surface and require more complex fish-farm management to control their proliferation. Nonetheless, promoting the co-production of macrophytes in an aquaecosystem may significantly reduce the negative economic and environmental impacts caused by the use of industrial fish feed, and may thus help promote sustainable development, equity and resilience of interlinked social and ecological systems MEA, 2005. The feasibility of co-culturing aquatic macrophytes within an aquaculture ecosystem strongly depends on local administration, local conditions and the macrophyte and fish species present in the aqua-ecosystem. For example, E. crassipes appears to be much more adapted to water quality remediation than to being a fish feed supplement. Conversely, Azolla and Lemna, which led to similar scores in our study, appear particularly well adapted for the partial substitution of fish feed. This is in agreement with previous studies showing the interest of those macrophytes as fish feed (Velásquez, 2016; Asimi et al., 2018; Das et al., 2018). Considering the limited impacts of macrophytes on water quality in our experimental pond conditions and commercial fish feed cost, the partial substitution of fish feed by macrophytes co-produced in situ would be a promising way to enhance sustainability of small scale fish farming. Conditions of co-culture, mode of distribution to the fish and impacts of macrophytes on fish performances and welfare should be determined in each specific system. Ultimately, the choice of macrophyte will vary according to the eco-services required (bio-remediation, fish feeding, fodder production) and needs to be done according to the local field conditions. In this perspective, the methodology proposed here for choosing macrophytes can be considered as a generic approach, applicable to a wide panel of aquaculture ecosystems.

Acknowledgments. This paper is a production of the COFASP ERA-NET project "IMTA-EFFECT" funded by the European Union and French National Research Agency. This is publication ISEM 2018-169. 


\section{References}

Akmal M, Hafeez-ur-Rehman M, Ullah S, Younus N, Khan KJ, Qayyum M. 2014. Nutritive value of aquatic plants of Head Baloki on Ravi River, Pakistan. Int J Biosci 4: 115-122.

AOAC Association of Official Analytical Chemists. Official methods of analysis of AOAC International. 16th Ed. Maryland (USA) J. Assoc. Off. Anal. Chem, 1999

Asimi OA, Khan IA, Bhat TA, Husain, N. 2018. Duckweed (Lemna minor) as a plant protein source in the diet of common carp (Cyprinus carpio) fingerlings. $J$ Pharmacogn Phytochem 7: $42-45$

Aubin J, Rey-Valette H, Mathé S, Wilfart-Monziols A, Legendre M, Slembrouck J, Chia E, Masson G, Callier M, Blancheton JP, Tocqueville A, Caruso D, Fontaine P. 2014. Guide de mise en œuvre de l'intensification écologique pour les systèmes aquacoles. INRA-Rennes, p. 131 ISBN: 978-2-9547969-0-2.

Aubin J, Callier M, Rey-Valette H, Mathé S, Wilfart A, Legendre M, Slembrouck J, Caruso D, Chia E, Masson G, Blancheton J-P, Ediwarman, Haryadi J, Prihadi TH, de Matos Casaca J, Tamassia STJ, Tocqueville A, Fontaine P. 2017. Implementing ecological intensification in fish farming: definition and principles from contrasting experiences. Rev Aquacult 1-19. DOI: 10.1111/ raq. 12231.

Bairagi A, Ghosh KS, Sen SK, Ra AK. 2002. Duckweed (Lemna polyrhiza) leaf meal as a source of feedstuff in formulated diets for rohu (Labeo rohita Ham.) fingerlings after fermentation with a fish intestinal bacterium. Bioresour Technol 85: 17-24.

Barko JW, Hardin DG, Matthews MS. 1982. Growth and morphology of submersed freshwater macrophytes in relation to light and temperature. Can. J. Bot. 60: 877-887.

Bommarco R, Kleijn D, Potts SG. 2013. Ecological intensification: harnessing ecosystem services for food security. Trends Ecol Evol 28: $230-238$.

Bosma RH, Verdegem MC. 2011. Sustainable aquaculture in ponds: principles, practices and limits. Livest Sci 139: 58-68.

Carlozzi P, Padovani G. 2016. The aquatic fern Azolla as a natural plant-factory for ammonia removal from fish-breeding fresh wastewater. Environ Sci Pollut Res 23: 8749-8755.

Carr GM, Duthie HC, Taylor WD. 1997. Models of aquatic plant productivity: a review of the factors that influence growth. Aquat Bot 59: 195-215.

Crispim MC, Vieira ACB, Coelho SFM, Medeiros AMA. 2009. Nutrient uptake efficiency by macrophyte and biofilm: practical strategies for smallscale fish farming. Acta Limnol Bras 21: 387-391.

Das M, Rahim FI, Hossain MA. 2018. Evaluation of fresh Azolla pinnata as a low-cost supplemental feed for Thai Silver Barb Barbonymus gonionotus. Fishes 3: 15.

Drew MD, Borgeson TL, Thiessen DL. 2007. A review of processing of feed ingredients to enhance diet digestibility in finfish. Anim Feed Sci Technol 138: 118-136.

Dersjant-Li Y. 2002. The use of soy protein in aquafeeds. Avances en Nutricion Acuicola VI Memorias del VI Simposium Internacional de Nutricion Acuicola 3: 541-558.

Dhote S, Dixit S. 2009. Water quality improvement through macrophytes - a review. Environ Monit Assess 152: 149-153.

Elfitasari T, Albert A. 2017. Challenges encountered by small scale fish farmers in assuring fish product sustainability. Omni-Akuatika 13: $128-136$.

El-Sayed AFM. 2003. Effects of fermentation methods on the nutritive value of water hyacinth for Nile tilapia Oreochromis niloticus (L.) fingerlings. Aquaculture 218: 471-478.
FAO. 2018. The state of world fisheries and aquaculture 2016. Contributing to food security and nutrition for all, Rome p. 200

Ferdoushi Z, Haque F, Khan S, Haque M. 2008. The effects of two aquatic floating macrophytes (Lemna and Azolla) as biofilters of nitrogen and phosphate in fish ponds. Turk J Fish Aquat Sci 8: 253 258.

Fiogbé ED, Micha JC, Van Hove C. 2004. Use of a natural aquatic fern, Azolla microphylla, as a main component in food for the omnivorous-phytoplanktonophagous tilapia, Oreochromis niloticus L. J Appl Ichthyol 20: 517-520.

Gaitlin DM, Barrows FT, Brown P, Dabrowski K, Gaylord TG, Hardy RW, Herman E, Hu G, Krogdahl A, Nelson R, Overturf K, Rust M, Sealy W, Skonberg D, Souza EJ, Stone D, Rich Wilson R, Wurtele E. 2007. Expanding the utilization of sustainable plant products in aquafeeds: a review. Aquacult Res 38: 551-579.

Goopy JP, Murray PJ. 2003. A review on the role of duckweed in nutrient reclamation and as a source of animal feed. AsianAustralas J Anim Sci 16: 297-305.

Griffon M. 2010. Pour des agricultures écologiquement intensives des territoires à haute valeur environnementale et de nouvelles politiques agricoles. Éd. De l'Aube (Monde en cours), La Tour d'Aigues, $144 \mathrm{p}$.

Hasan MR, Rina C. 2009. Use of algae and aquatic macrophytes as feed in small-scale aquaculture: a review. FAO Fisheries and Aquaculture Technical Paper, 531, 123 p.

Henry-Silva GG, Camargo AFM. 2006. Efficiency of aquatic macrophytes to treat Nile tilapia pond effluents. Sci Agric 63: 433-438.

Invasive Species Specialist Group ISSG. The Global Invasive Species Database. Version 2015.1., 2015

Iqbal S. 1999. Duckweed aquaculture. Potentials, possibilities and limitations for combined wastewater treatment and animal feed production in developing countries. SANDEC Report n 6/99, 91 p.

Kasumyan AO, Doving, KB. 2003. Taste preferences in fishes. Fish Fish 4: 289-347.

Kollah B, Patra AK, Mohanty SR. 2016. Aquatic microphylla Azolla: a perspective paradigm for sustainable agriculture, environment and global climate change. Environ Sci Pollut Res 23: 4358-4369.

Kawarazuka N, Béné C. 2010. Linking small-scale fisheries and aquaculture to household nutritional security: an overview. Food Secur 2: 343-357.

Madsen TV, Cedergreen N. 2002. Sources of nutrients to rooted submerged macrophytes growing in a nutrient-rich stream. Freshwater Biol 2: 283-291.

Mandal RN, Datta AK, Sarangi N, Mukhopadhyay PK. 2010. Diversity of aquatic macrophytes as food and feed components to herbivorous fish-a review. Indian J Fish 57: 65-73.

MEA, Millennium Ecosystem Assessment. Ecosystems and human well-being: synthesis. Island Press, Washington DC, 2005 160p. ISBN: 9781597260404.

Muradov N, Taha M, Miranda AF, Kadali K, Gujar A, Rochfort S, Stevenson T, Ball AS, Mourado, A. 2014. Dual application of duckweed and azolla plants for wastewater treatment and renewable fuels and petrochemicals production. Biotechnol Biofuels 7: 30 .

Newton JW, Herman AI. 1979. Isolation of cyanobacteria from the aquatic fern, Azolla. Arch Microbiol 120: 161-165.

Phillips M, Henriksson PJG, Tran N, Chan CY, Mohan CV, Rodriguez U-P, Suri S, Hall S, Koeshendrajana S. 2015. Exploring Indonesian aquaculture futures. Penang, Malaysia: WorldFish. Program Report, 2015-39, 15 p.

Sipaúba-Tavares LH, Favero EGP, Braga FDS. 2002. Utilization of macrophyte biofilter in effluent from aquaculture: I. Floating plant. Braz J Microbiol 62: 713-723. 
Soto D, Aguilar-Manjarrez J, Brugère C, Angel D, Bailey C, Black K, Edwards P, Costa-Pierce B, Chopin T, Deudero S, Freeman S, Hambrey J, Hishamunda N, Knowler D, Silvert W, Marba N, Mathe S, Norambuena R, Simard F, Tett P, Troell M, Wainberg A, in: D. Soto, J. Aguilar-Manjarrez and N. Hishamunda (Eds.), Applying an ecosystem-based approach to aquaculture: principles, scales and some management measure, Building an ecosystem approach to aquaculture, FAO Fisheries and Aquaculture Proceedings 14, Rome, 2008 pp. 15-35.

Redding T, Todd S, Midlen A. 1997. The treatment of aquaculture wastewaters - a botanical approach. $J$ Environ Manage 50: 283-299.

Reddy KR, De Busk WF. 1985. Nutrient removal potential of selected aquatic macrophytes. J Environ Qual 14: 459-462.
Shiomi N, Kitoh S. 2001. Culture of Azolla in a pond, nutrient composition, and use as fish feed. Soil Sci Plant Nutr 47: 27-34.

Tacon AG, Metian M. 2015. Feed matters: satisfying the feed demand of aquaculture. Rev Fish Sc 23: 1-10.

Tacon AG, Metian M. 2018. Food Matters: fish, Income, and food Supply - a comparative analysis. Rev Fish Sci 26: 1-14.

Velásquez YCC. Study on the locally available aquatic macrophytes as fish feed for rural aquaculture purposes in South America (Doctoral dissertation, Humboldt-Universität zu Berlin, Landwirtschaftlich-Gärtnerische Fakultät), 2016. DOI: 10.18452/ 17510.

Y1lmaz E, Akyurt İ, Günal G. 2004. Use of duckweed, Lemna minor, as a protein feedstuff in practical diets for common carp, Cyprinus carpio, fry. Turk J Fish Aquat Sci 4: 105-109.

Cite this article as: Slembrouck J, Samsudin R, Pantjara B, Sihabuddin A, Legendre M, Caruso D. 2018. Choosing floating macrophytes for ecological intensification of small-scale fish farming in tropical areas: a methodological approach. Aquat. Living Resour. 31 : 30 